Article

\title{
Improving Energy Efficiency of Barley Production Using Joint Data Envelopment Analysis (DEA) and Life Cycle Assessment (LCA): Evaluation of Greenhouse Gas Emissions and Optimization Approach
}

\author{
Zahra Payandeh ${ }^{1}$, Ahmad Jahanbakhshi ${ }^{1}$, Tarahom Mesri-Gundoshmian ${ }^{1}$ and Sean Clark ${ }^{2, *(D)}$ \\ 1 Department of Biosystems Engineering, University of Mohaghegh Ardabili, Ardabil 56199-11367, Iran; \\ z.payandeh92@gmail.com (Z.P.); ahmad.jahanbakhshi@uma.ac.ir (A.J.); mesrigtm@uma.ac.ir (T.M.-G.) \\ 2 Department of Agriculture and Natural Resources, Berea College, Berea, KY 40404, USA \\ * Correspondence: clarks@berea.edu
}

check for updates

Citation: Payandeh, Z;

Jahanbakhshi, A.;

Mesri-Gundoshmian, T.; Clark, S. Improving Energy Efficiency of Barley Production Using Joint Data Envelopment Analysis (DEA) and Life Cycle Assessment (LCA): Evaluation of Greenhouse Gas Emissions and Optimization Approach. Sustainability 2021, 13, 6082. https://doi.org/10.3390/ su13116082

Academic Editor: Antonio Boggia

Received: 3 April 2021

Accepted: 24 May 2021

Published: 28 May 2021

Publisher's Note: MDPI stays neutral with regard to jurisdictional claims in published maps and institutional affiliations.

Copyright: (c) 2021 by the authors. Licensee MDPI, Basel, Switzerland. This article is an open access article distributed under the terms and conditions of the Creative Commons Attribution (CC BY) license (https:/ / creativecommons.org/licenses/by/ $4.0 /)$.

\begin{abstract}
Eco-efficiency has become a cornerstone in improving the environmental and economic performance of farms. The joint use of life cycle assessment (LCA) and data envelopment analysis (DEA), known as LCA + DEA methodology, is an expanding area of research in this quest. LCA estimates the environmental impacts of the products or services, while DEA evaluates their efficiency, providing targets and benchmarks for the inefficient ones. Because energy consumption and environmental quality are highly interdependent, we carried out a study to examine energy efficiency and environmental emissions associated with rain-fed barley farms in Kermanshah Province, Iran. Fifty-four rain-fed barley farms were randomly selected, and production data were collected using questionnaires and interviews. DEA and LCA were used to quantify and compare environmental indicators before and after efficiency improvements were applied to the farms. To accomplish this, efficient and inefficient farms were identified using DEA. Then environmental emissions were measured again after inefficient farms reached the efficiency limit through management improvements. The results showed that by managing resource use, both energy consumption and environmental emissions can be reduced without yield loss. The initial amount of energy consumed averaged $13,443 \mathrm{MJ} / \mathrm{h}$ a while that consumed in the optimal state was determined to be $12,509 \mathrm{MJ} / \mathrm{h}$, resulting in a savings of $934 \mathrm{MJ} / \mathrm{ha}$. Based on the results of DEA, reductions in nitrogen fertilizer, diesel fuel, and phosphate fertilizer offered the greatest possibilities for energy savings. Combining DEA and LCA showed that efficient resource management could reduce emissions important to abiotic depletion (fossil fuels), human toxicity, marine aquatic ecotoxicity, global warming (GWP100a), freshwater aquatic ecotoxicity, and terrestrial ecotoxicity. This study contributes toward systematically building knowledge about crop production with the joint use of LCA + DEA for eco-efficiency assessment.
\end{abstract}

Keywords: barley; GHG emissions; energy use efficiency; optimization; LCA + DEA

\section{Introduction}

Energy consumption in agriculture has increased to meet the needs of the growing human population, while available arable land has declined, and labor shortages have become more common [1,2]. However, excessive energy consumption has had consequences for agricultural sustainability and environmental quality. Consumption of agricultural inputs during agricultural operations like spraying, irrigation, fertilization, harvesting, and land preparation, discharges greenhouse gases (GHG) and other pollutants into the environment. Improving energy efficiency is therefore fundamental for reducing environmental damage, protecting natural resources, and ensuring agricultural sustainability [3,4]. It is essential that we identify sources of GHG emissions and take specific measures to reduce them [5-8]. 
Barley (Hordeum vulgare L.) is among the world's most important cereal crops, ranking fourth in total production after wheat, maize, and rice. Barley grows rapidly, suppresses weeds, and provides high yields in terms of dry weight, but it provides a low-protein forage. Like rice, barley is an important crop in Iran since its availability and price greatly affect the capacity of local livestock production. A total of 19.5 million tons of cereal grains were produced in Iran in 2015-2016, of which 3.8 million tons were barley grain. However, it is estimated that the country requires another 1.3 million tons of imported barley [9].

Sustainable agricultural production provides food security and decreases environmental impacts by consuming resources more efficiently. Globally, among all environmental pollutants, GHG emissions are arguably the most detrimental to the environment and economy $[5,10]$. Various studies have evaluated energy flows and input-output efficiencies in crop production at national and international scales, including wheat [11]; barley [12]; chickpea [13]; wheat and sugar beet, [14] and chestnut [15]. However, few reports have addressed energy consumption in barley production and the associated environmental impacts, particularly those of GHG emissions [16-18].

The agricultural sector is a major source of GHGs, such as carbon dioxide $\left(\mathrm{CO}_{2}\right)$, nitrous oxide $\left(\mathrm{N}_{2} \mathrm{O}\right)$, and methane $\left(\mathrm{CH}_{4}\right)$. Because of the economic importance and large cultivated area of barley, identifying the main sources of GHGs in this crop can provide potentially consequential options for reducing those emissions. Life cycle assessment (LCA) is a valuable approach to determining the environmental impacts associated with all production stages of a commodity, including GHGs [9,18-20].

Data envelopment analysis (DEA) is a non-parametric approach to assess the relative efficiency of decision-making units (DMUs) in multi-input and output production systems. DEA has been applied in agricultural studies to determine efficiencies of various crop and livestock production systems. Many researchers have endorsed DEA as being a useful method for estimating relative energy efficiency in agriculture and livestock. The main reason for using this method in agricultural and livestock activities is that it does not need any prior assumptions on the underlying functional relationships between inputs and outputs [21-23].

In this study we combine DEA and LCA, enabling us to recognize efficient producers by accounting for economic as well as environmental performance. There are three different classifications for the LCA + DEA framework which include either three-, four-, or five-step processes $[3,5,22,24]$. Undesirable outputs are treated differently in each classification method. Such treatments can include: (a) ignoring undesirable outputs in the DEA model, (b) treating undesirable outputs as inputs to the DEA model, (c) data transformation, (d) impact rate, (e) ratio model, and (f) slack-based measurement (SBM) as described by Pishgar-Komleh et al. [5]. Considering that: (1) different scenarios and approaches can be applied for the LCA + DEA framework; (2) few studies on crop production systems in Iran have combined LCA and DEA, and (3) no study to date has employed and evaluated the DEA model with undesirable outputs for barley production, this study combines LCA and DEA using alternative methods to find an appropriate DEA model for evaluating the environmental efficiency of the barley production in Iran. The results of this study can serve as a support for applying optimal production approaches to achieve the highest production rate with the lowest environmental impact.

\section{Materials and Methods}

\subsection{Sampling and Data Collection}

This study was performed in Kermanshah Province (within $33^{\circ} 37^{\prime}$ latitude and $45^{\circ} 20^{\prime}$ longitude) in western Iran (Figure 1). In this region, barley cultivation occurs in the autumn and is rain-fed. Among the rain-fed crops, barley ranks second in Iran with 1.1 million tons of annual production. Kermanshah Province ranks first in barley production in Iran with $19.4 \%$ of the total. 


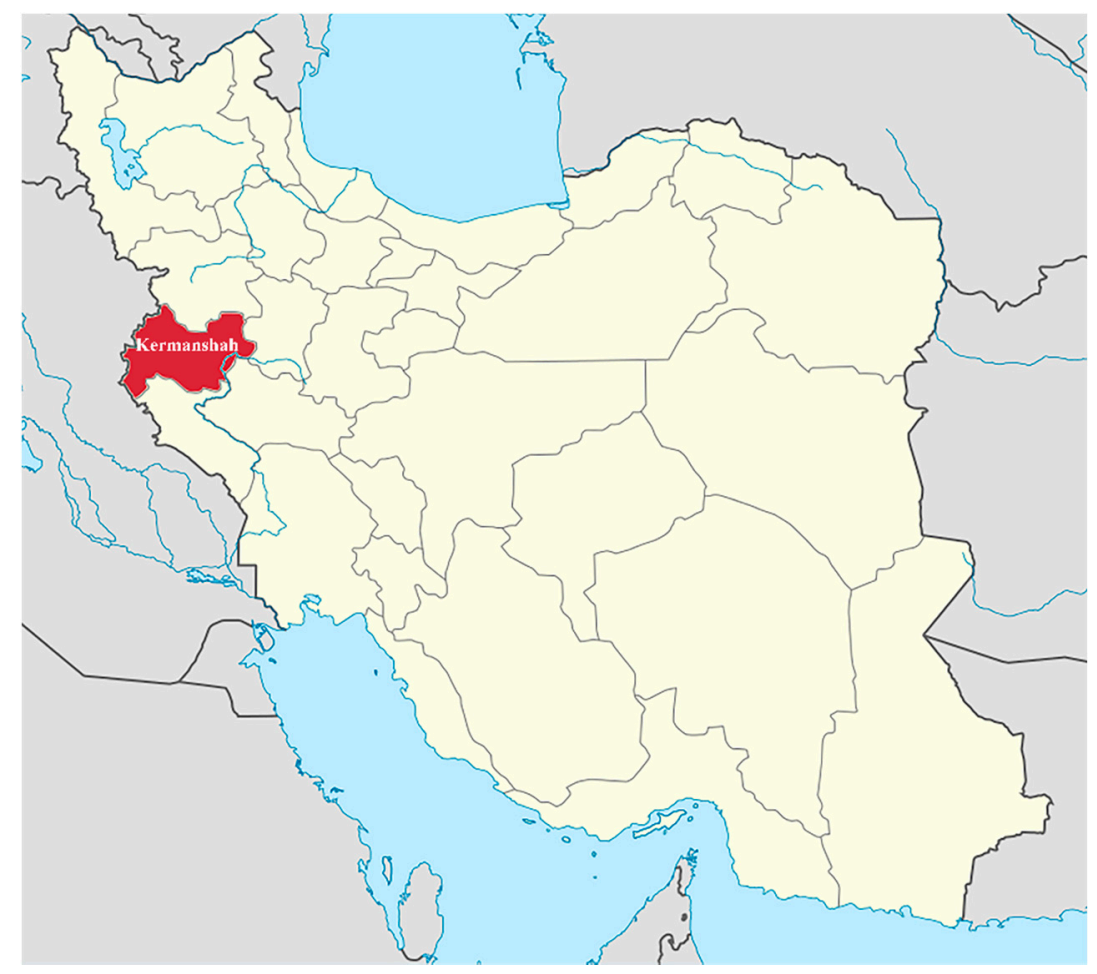

Figure 1. Geographical map of Kermanshah Province, Iran.

The data for this study were collected through a questionnaire administered to 54 farmers during the 2019 crop year to obtain information on inputs (including barley seeds, human labor, fuel, chemical fertilizers, chemical pesticides, and machinery) and outputs (barley grain yield and barley straw yield). In this study, all farms were in an area with similar climatic and soil conditions. Farm efficiency was measured and assessed using the amounts of input and output energy. The number of samples was determined using the Cochrane relation (Equation (1)) [25].

$$
n=\frac{N t^{2} S^{2}}{N d^{2}+t^{2} S^{2}}
$$

In Equation (1), $n$ is the statistical population of the farmers who raise barley in the area under study; $t$ is the acceptable reliability coefficient which can be obtained from the Student's t-table assuming that the given feature is normally distributed. $S^{2}$ estimates the variance of the feature studied in the population, $d$ is the probable optimal accuracy (half the confidence interval), and $n$ is the sample size $(N=100 ; t=1.96 ; d=0.05 ; S=0.277)$.

\subsection{Energy of the Inputs and Energy Indicators}

The energy equivalent coefficients indicate the amounts of energy per unit input and output (Table 1). The energy equivalent of each input or output is calculated by multiplying the amount of each input or output by the appropriate energy equivalent coefficient. 
Table 1. Energy equivalent coefficients for barley.

\begin{tabular}{|c|c|c|c|}
\hline Items & Unit & Energy Equivalent (MJ) & References \\
\hline \multicolumn{4}{|l|}{ A. Inputs } \\
\hline 1. Human labor & $\mathrm{h}$ & 1.96 & [26] \\
\hline 2. Diesel fuel & $\mathrm{L}$ & 56.31 & [26] \\
\hline 3. Oil & $\mathrm{L}$ & 47.80 & [27] \\
\hline \multicolumn{4}{|l|}{ 4. Machinery } \\
\hline $\begin{array}{l}\text { (a) Combine } \\
\text { (b) Other }\end{array}$ & $\mathrm{h}$ & 87.63 & [28] \\
\hline $\begin{array}{l}\text { agricultural } \\
\text { machinery }\end{array}$ & $\mathrm{h}$ & 62.70 & [28] \\
\hline $\begin{array}{l}\text { 5. Chemical fertilizers } \\
\text { (a) Nitrogen (N) }\end{array}$ & $\mathrm{kg}$ & 66.14 & [28] \\
\hline $\begin{array}{l}\text { (b) Phosphate } \\
\text { (P2O5) }\end{array}$ & $\mathrm{kg}$ & 12.44 & [28] \\
\hline \multicolumn{4}{|l|}{ 6. Chemicals } \\
\hline (a) Herbicides & $\mathrm{L}$ & 238.00 & [29] \\
\hline (b) Insecticides & $\mathrm{L}$ & 199.00 & [29] \\
\hline 7. Seeds & $\mathrm{kg}$ & 14.70 & [30] \\
\hline \multicolumn{4}{|l|}{ B. Outputs } \\
\hline 1. Grain yield & $\mathrm{kg}$ & 14.47 & [30] \\
\hline 2. Straw yield & $\mathrm{kg}$ & 12.50 & [30] \\
\hline
\end{tabular}

Based on input and output energies, energy indicators which include energy ratio, energy use efficiency, specific energy, and net energy were calculated using Equations (2)-(5). These indicators make it possible to study and compare systems in more detail [30].

$$
\begin{gathered}
\text { Energy ratio }=\frac{\text { Energy output }\left(\frac{\mathrm{MJ}}{\mathrm{ha}}\right)}{\text { Energy input }\left(\frac{\mathrm{MJ}}{\mathrm{ha}}\right)} \\
\text { Energy use efficiency }=\frac{\text { Yield of barley }\left(\frac{\mathrm{kg}}{\mathrm{ha}}\right)}{\text { Energy input }\left(\frac{\mathrm{MJ}}{\mathrm{ha}}\right)} \\
\text { Specific energy }=\frac{\text { Energy input }(\mathrm{MJ} / \mathrm{ha})}{\text { Yield of barley }(\mathrm{kg} / \mathrm{ha})} \\
\text { Net energy }=\text { Energy output }(\mathrm{MJ} / \text { ha })-\text { Energy input }(\mathrm{MJ} / \mathrm{ha})
\end{gathered}
$$

\subsection{Data Envelopment Analysis (DEA)}

DEA is a non-parametric method for estimating production functions based on a series of optimizations using linear programming. The method examines the efficiencies of the DMUs using efficiency limits based on the energy consumption levels of the most efficient units (those DMUs with the most desirable level of energy consumption). This method was first proposed by Charns et al. [31], abbreviated as CCR (Charns, Cooper, and Rhodes), and known as the model with constant returns to scale. It was then expanded by Banker et al. [32], abbreviated as BCC, and known as the model with variable returns to scale. In the CCR model, technical efficiency (TE) is calculated and in the BCC model pure technical efficiency (PTE) is calculated. Technical efficiency (TE) evaluates the efficiency of units relative to each other. Scale efficiency (SE) is the ratio of TE to PTE and shows the effect of size on system efficiency. PTE is a technical efficiency that eliminates the impact of the efficiency scale.

Figure 2 graphically displays the BCC and CCR models. The MN line is the production boundary of the CCR model and the red broken line is the production boundary of the BCC model. According to Figure 2, the $\mathrm{P}_{2}$ unit is efficient in the CCR model and in the BCC model; the $\mathrm{P}_{1}, \mathrm{P}_{2}, \mathrm{P}_{3}$, and $\mathrm{P}_{4}$ units are efficient, and their efficiency is equal to 1 . The 
remaining units are efficient based on the BCC model but not efficient in the CCR model and have scale inefficiencies.

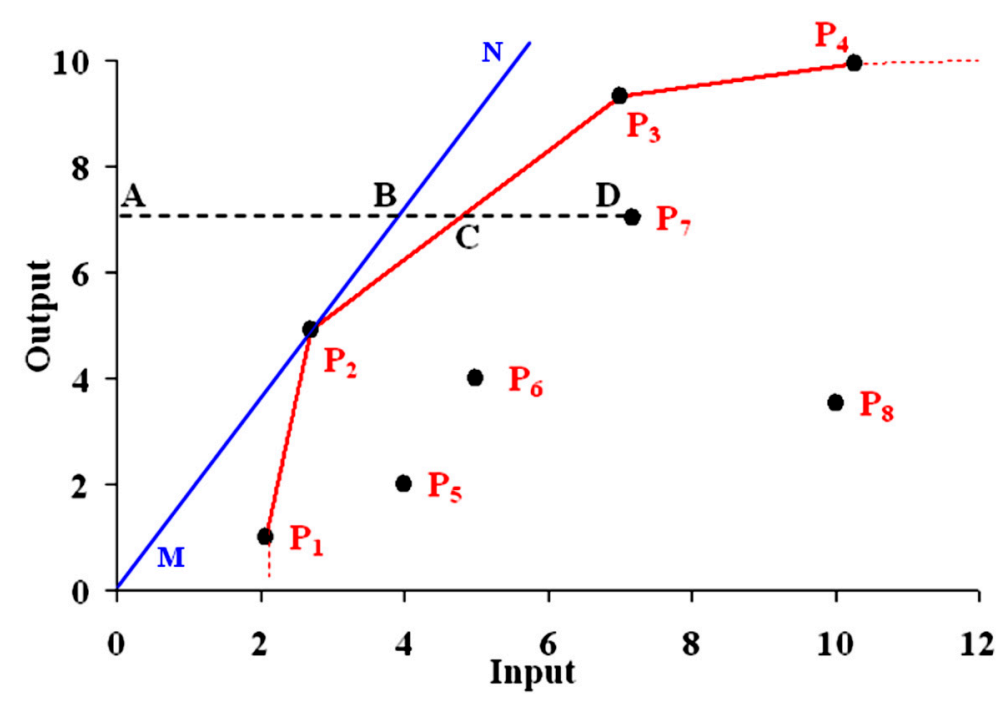

Figure 2. Graphical illustrations of BCC and CCR models.

DEA models can be either output-oriented or input-oriented. The output-oriented model maximizes output while keeping the input rate constant while an input-oriented model keeps the output value constant so that the unit in question reaches the efficiency limit. EMS software Version 1.3 with the input-oriented CCR model of efficiency measurement systems (EMS) was used to evaluate the efficiency of the farms or DMUs [33].

\subsection{Life Cycle Assessment (LCA)}

LCA can be used in assessing and estimating the environmental effects associated with an agricultural product along each stage of its life cycle. According to ISO 14040 and ISO 14044 standards, this method has four steps, which include goal and domain definition, inventory analysis, impact assessment, and interpretation of results. Determining the system boundary, defining the functional unit, and allocating resources are among the goals of the first step. Nemecek et al. [34] proposed three different functional units for product evaluation based on: (1) land area; (2) currency; (3) yield of the material produced. The functional unit selected for this study was 1 ton of barley and the boundary was the farm system.

Inventory analysis, system resources, raw materials and resources, types of energy and emissions of pollutants into water, air and soil are introduced into the second phase of the LCA, known as life cycle inventory (LCI). The emission factors for the input variables were calculated based on Nemecek et al. [35]. The emission factors resulting from the combustion of $1 \mathrm{~L}$ of diesel was calculated according to the research of Payandeh et al. [3]. Among the gaseous emissions, carbon dioxide $\left(\mathrm{CO}_{2}\right)$, sulfur oxide $\left(\mathrm{SO}_{2}\right)$, and nitrogen oxide $\left(\mathrm{NO}_{\mathrm{X}}\right)$ are particularly important. SimaPro software was used for calculating the emissions of the other inputs. The impact assessment (IA) step provides a framework for tracking and quantifying the input and output currents of the materials and the energy associated with the product or process. It is an integral part of LCA for understanding the potential environmental impacts of a production system and the relationship between inputs and outputs. The CML IA baseline V3.02/EU25/Characterization method was used to assess the environmental effects of barley cultivation [36,37]. Eleven impact groups were selected based on the inputs into barley crop cultivation.

Finally, at the interpretation stage the results are analyzed, conclusions are formed, and suggestions or recommendations are made to minimize the environmental effects of the system [38]. Strategies for improving the system are discussed and the results 
can be applied toward the intended application in the appropriate field, in this case, barley production.

\subsection{Combining LCA and DEA}

LCA measures the environmental impacts of input consumption within the boundary under study while DEA determines the appropriate levels of inputs to direct inefficient barley farms toward an efficiency threshold. The combination of the two methods $(\mathrm{LCA}+\mathrm{DEA})$ therefore guides farms (DMUs) toward greater efficiency while limiting environmental impacts. The combined LCA + DEA approach can play a role in energy policy making by determining the environmental impacts associated with choices of energy sources. DEA can be combined with LCA to provide quantitative benchmarks that orientate the performance of energy systems toward environmental sustainability. Thus, this approach can serve environmental managers in reducing input consumption and environmental damage associated with barley production. Figure 3 shows the schematic representation of the LCA + DEA method.

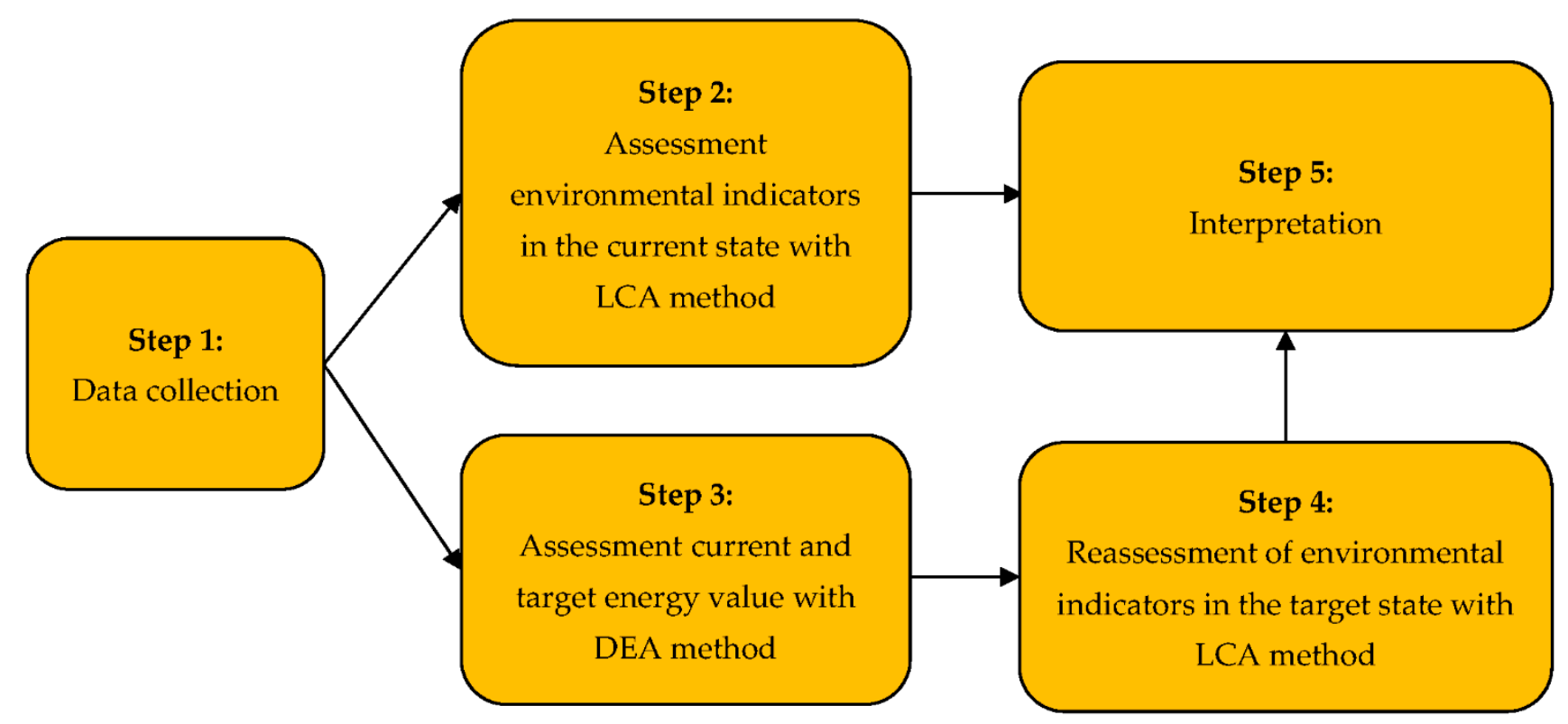

Figure 3. Schematic representation of the LCA + DEA method.

\section{Results and Discussion}

\subsection{Evaluation of Input and Output Energies and Energy Indicators}

The input and output energies for rain-fed barley production are reported in Table 2. On average, 13,443.20 MJ of energy was used from the various sources for cultivating 1 ha of rain-fed barley. The output energy from 1 ha of rain-fed barley was estimated to be $43,345 \mathrm{MJ} / \mathrm{ha}$.

The energy share for each of the inputs used in producing 1 ha of rain-fed barley is shown in Figure 4. Fertilizers, diesel fuel, and seed account for the largest shares at $44.85 \%$, $29.33 \%$, and $17.64 \%$, respectively. Among chemical fertilizers, $\mathrm{N}$ fertilizer (40\%) accounted for most of the total. $\mathrm{N}$ fertilizer, despite its effective role in increasing the growth and yield of crops, has always been a serious challenge in relation to energy consumption in agriculture [39].

The energy required to produce $1 \mathrm{~kg}$ of $\mathrm{N}$ is estimated at approximately $66.14 \mathrm{MJ}$, which is quite high compared to other fertilizers, especially livestock manure [40]. Despite this, $\mathrm{N}$ fertilizers are often used excessively due to: (1) a failure to conduct soil tests before fertilizer application; (2) a lack of awareness among farmers about the negative consequences of the excessive use of $\mathrm{N}$ fertilizers; (3) a lack of crop rotation [39]. 
Table 2. Inventory data for barley cultivation.

\begin{tabular}{|c|c|c|c|c|}
\hline Input/Output & Unit & Quantity Per Ha & $\begin{array}{l}\text { Energy Equivalent } \\
\text { (MJ) }\end{array}$ & $\begin{array}{c}\text { Mean Energy Value } \\
\text { (MJ/ha) }\end{array}$ \\
\hline \multicolumn{5}{|l|}{ Inputs } \\
\hline 1. Seed & $\mathrm{kg}$ & 161.30 & 14.70 & 2371.11 \\
\hline 2. Human labor & $\mathrm{H}$ & 12.14 & 1.96 & 23.80 \\
\hline 3. Diesel fuel & $\mathrm{L}$ & 70.01 & 56.31 & 3942.26 \\
\hline $\begin{array}{l}\text { 4. Agriculture } \\
\text { machinery }\end{array}$ & $\mathrm{kg}$ & 11.60 & 62.70 & 725.90 \\
\hline 5. Fertilizers & $\mathrm{kg}$ & & & \\
\hline Nitrogen $(\mathrm{N})$ & & 80.50 & 66.14 & 5324.30 \\
\hline Phosphate $\left(\mathrm{P}_{2} \mathrm{O}_{5}\right)$ & & 56.70 & 12.44 & 705.35 \\
\hline 6. Chemicals & $\mathrm{L}$ & & & \\
\hline Insecticide & & 0.52 & 199.00 & 105.10 \\
\hline Herbicide & & 1.03 & 238.00 & 245.60 \\
\hline Total energy inputs & & & & $13,443.20$ \\
\hline \multicolumn{5}{|l|}{ Outputs } \\
\hline 1. Barley & $\mathrm{kg}$ & 2038.00 & 14.70 & $29,958.60$ \\
\hline 2. Straw & $\mathrm{kg}$ & 1154.00 & 11.60 & $13,386.40$ \\
\hline Total energy outputs & & & & $43,345.00$ \\
\hline
\end{tabular}

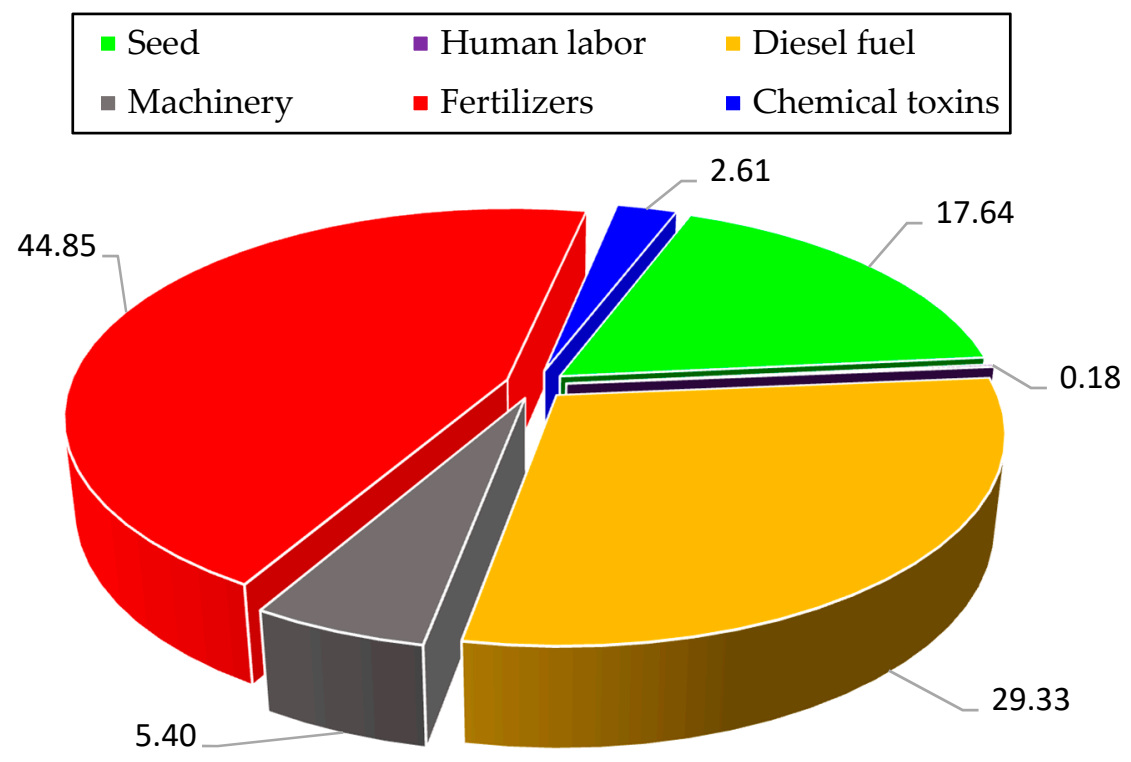

Figure 4. Total input energy contributions (\%) in rain-fed barley production.

Energy input and output values reported in the literature for wheat are relatively similar to those calculated here for barley. According to Taki et al. [41], the input and output energies for the cultivation of rain-fed wheat in Iran were determined to be 9.35 and $35.22 \mathrm{GJ} / \mathrm{ha}$, respectively. They reported that in rain-fed wheat fields, the share of the fertilizer input was estimated to be higher than the other inputs because farmers would spread fertilizer using human labor rather than machines and this increased consumption. Ghorbani et al. [11] determined the total input energies for irrigated and rain-fed wheat to be 43.37 and $9.35 \mathrm{GJ} / \mathrm{ha}$, respectively.

Human labor $(0.18 \%)$ and chemical pesticides $(2.61 \%)$ accounted for the smallest shares of total energy consumption among the inputs (Figure 4). These findings are similar to those reported by Neira et al. [42], Nabavi-Pelesaraei et al. [43], and Cerutti et al. [44]. A study by Singh et al. [45] showed that the total energy consumed to produce wheat under different weather conditions ranged between 13.06 and $17.90 \mathrm{GJ} / \mathrm{ha}$. In a study conducted by Abdollahpour and Zaree, [46] in Kermanshah Province, the amount of energy consumed in the 
production of rain-fed wheat was found to be $20.01 \mathrm{GJ} / \mathrm{ha}$. Fatolahi et al. [47] reported the amount of input and output energies in rain-fed wheat cultivation as 33.37 and $73.75 \mathrm{GJ} / \mathrm{ha}$, respectively, with chemical fertilizers and fuel at 15.04 and $3.73 \mathrm{GJ} / \mathrm{ha}$, respectively.

Table 3 shows the energy consumption indicators for rain-fed barley production in this study compared with those of other studies conducted in Iran. In these other studies, energy indicators were applied to compare energy consumption in different production systems. The energy ratio is unitless and shows the amount of energy obtained per unit of energy consumed during production. The energy ratio for barley cultivation in the area under study was 3.22, meaning that for each unit of energy consumed, 3.22 units of energy are produced through barley cultivation. These results are similar to those reported by Mondani et al. [48] and Ghorbani et al. [11] for rain-fed wheat cultivation. Energy efficiency, calculated by dividing the amount of the product by the energy consumed and thereby expressing the amount of production per unit of the energy consumed, was determined to be $151.64 \mathrm{Kg} / \mathrm{GJ}$, which is similar to results of previous studies in Iran.

Table 3. Comparison of energy consumption indicators in barley production with other studies.

\begin{tabular}{cccccc}
\hline Indicators & Unit & $\begin{array}{c}\text { Present Study } \\
\text { (2020) for Barley }\end{array}$ & $\begin{array}{c}\text { Taki et al. [41] for } \\
\text { Wheat }\end{array}$ & $\begin{array}{c}\text { Mondani et al. } \\
\text { [48] for Wheat }\end{array}$ & $\begin{array}{c}\text { Ghorbani et al. } \\
\text { [11] for Wheat }\end{array}$ \\
\hline Input energy & GJ & 13.44 & 9.35 & 15.6 & 9.354 \\
Output energy & GJ & 43.34 & 35.22 & 60.13 & 31.67 \\
Energy ratio & - & 3.22 & 4.11 & 3.85 & 3.38 \\
Energy use efficiency & $\mathrm{kg} / \mathrm{GJ}$ & 151.64 & 149.6 & 98.6 & 111.61 \\
Net energy & $\mathrm{GJ} / \mathrm{ha}$ & 29.9 & 29.14 & 44.52 & 22.32 \\
\hline
\end{tabular}

\subsection{Determining Farm Efficiency through DEA}

As shown in Table 4, a range of efficiencies were found among the rain-fed barley farms in this study with some reaching total efficiency. In other words, these farms have $100 \%$ efficiency, pure technical efficiency and scale efficiency. However, other farms had lower efficiencies in the same area, indicating possibilities for increasing production and improving performance under current circumstances. An important point to note about the results of this efficiency analysis is that the average pure technical efficiency is high, indicating that the farmers are generally highly skilled in cultivating rain-fed barley. Research has shown that in the absence of environmental differences (soil quality, water quality, climate, and pests) and measurement errors, pure technical efficiency can show differences among farmers in terms of their performance in managing their agricultural units [49].

Table 4. Efficiency scales found in the barley farms studied.

\begin{tabular}{ccccc}
\hline Efficiency Scale & Minimum & Mean & Maximum & Standard Deviation \\
\hline Technical efficiency & 0.79 & 0.93 & 1.00 & 0.06 \\
Pure technical & 0.85 & 0.96 & 1.00 & 0.05 \\
efficiency & 0.89 & 0.97 & 1.00 & 0.03 \\
Scale efficiency & 0.97 \\
\hline
\end{tabular}

Pure technical efficiency is applicable to short-term planning but not an appropriate criterion for setting goals of productivity and efficiency improvement. So, for long-term policy making, attention must be paid to increasing scale efficiency in addition to technical efficiency. As shown in Table 4, technical efficiency has the highest dispersion, indicating that not all farmers were aware of best production methods or were not using particular inputs in the optimal amounts or best times.

Figure 5 presents the efficiencies of the farms using two models: CCR and BCC. According to these results, 15 and 23 farms had 100\% efficiency according to the CCR and BCC models, respectively, and the remaining farms are considered inefficient to varying degrees. 


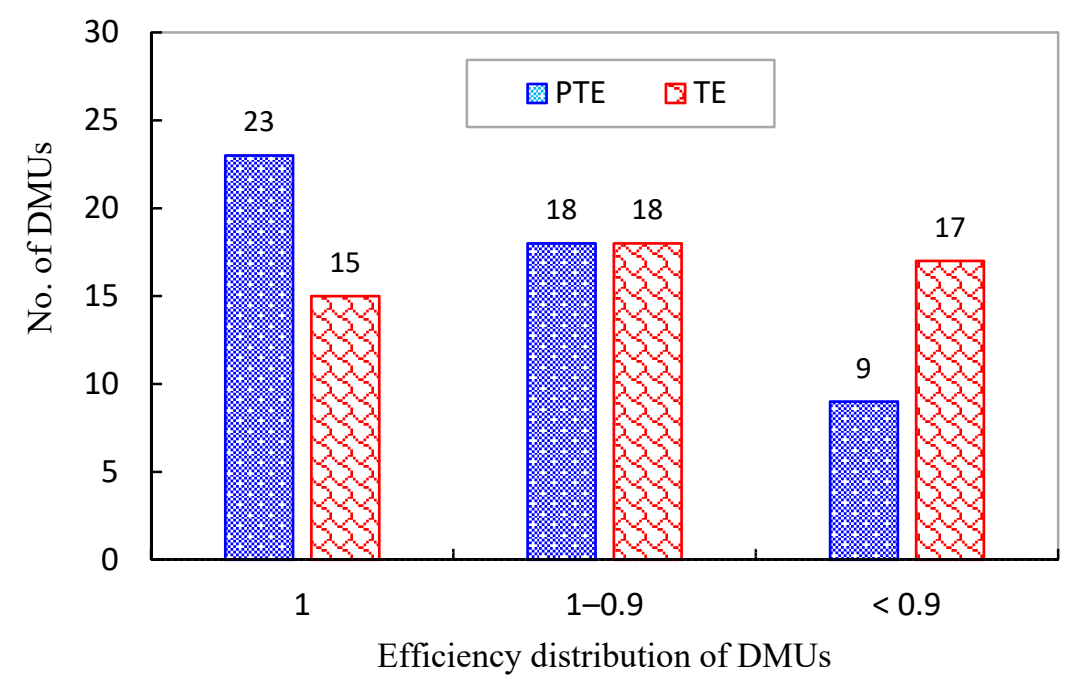

Figure 5. Efficiency DMUs using CCR and BCC models. The CCR model uses technical efficiency (TE), and the BCC model uses pure technical efficiency (PTE).

To compare efficient and inefficient farms, Table 5 presents energy values for current farm inputs, optimal target values, and the resulting energy savings according to the BCC model. The total amount of energy required was 13,443.20 MJ/ha while the amount of energy in the optimal state was 12,509.27 MJ/ha. Improving $\mathrm{N}$ fertilizer use had the greatest potential for energy savings at $363.35 \mathrm{MJ} / \mathrm{ha}$. The results indicate that $933.91 \mathrm{MJ} / \mathrm{ha}$ of the total input energy in rain-fed barley cultivation in the study area can be saved without a reduction in yield.

Table 5. Current and target energy values for rain-fed barley production in this study.

\begin{tabular}{|c|c|c|c|c|}
\hline \multirow{2}{*}{ Inputs } & \multicolumn{2}{|c|}{ Energy Value (MJ/ha) } & \multirow{2}{*}{$\begin{array}{c}\text { Energy Savings } \\
\text { (MJ/ha) }\end{array}$} & \multirow{2}{*}{$\begin{array}{c}\text { Energy Savings } \\
(\%)\end{array}$} \\
\hline & Current & Target & & \\
\hline 1. Seed & 2371.11 & 2210.63 & 160.48 & 6.77 \\
\hline 2. Human labor & 23.79 & 22.14 & 1.65 & 6.94 \\
\hline 3. Diesel fuel & 3942.04 & 3659.33 & 282.71 & 7.17 \\
\hline 4. Machinery & 725.94 & 675.35 & 50.59 & 6.97 \\
\hline \multicolumn{5}{|l|}{ 5. Fertilizers } \\
\hline Nitrogen $(\mathrm{N})$ & 5324.27 & 4960.92 & 363.35 & 6.82 \\
\hline Phosphate $\left(\mathrm{P}_{2} \mathrm{O}_{5}\right)$ & 705.35 & 654.35 & 51.00 & 7.23 \\
\hline \multicolumn{5}{|l|}{ 6. Chemicals } \\
\hline Insecticide & 105.07 & 97.67 & 7.40 & 7.04 \\
\hline Herbicide & 245.62 & 228.88 & 16.73 & 6.82 \\
\hline Total & $13,443.20$ & $12,509.27$ & 933.91 & 55.76 \\
\hline
\end{tabular}

For comparison, a study on energy efficiency optimization for wheat production in India by Singh et al. [45] showed that $85.2 \%$ of the electricity energy could be saved. In another study, Chauhan et al. [50] concluded that if farmers in India followed their proposed recommendations it would be possible to apply just $11.6 \%$ of the total energy consumed for rice production without any reduction in output.

Fertilization based on soil tests and plant needs, crop rotations, applications of composts, and incorporating green manures can be effective in reducing the need for chemical fertilizers, especially $\mathrm{N}$ fertilizer in rain-fed barley cultivation. Diesel fuel consumption may be reduced by minimizing repeated machine use in the fields as much as possible, such as with the use of combine harvesters. Regarding the amounts of barley seed used, the use of precision sowing equipment instead of manual sowing can be a means of reducing seed consumption. 


\subsection{Results of Combining DEA and LCA}

The DEA method determines resource amounts needed to optimize each DMU or farm. The environmental indicators were examined at current and target input levels (Table 6) and the comparison shows that if inefficient farms are managed efficiently, reductions in all inputs are possible, with associated reductions in environmental emissions but without any change in output. The DEA method indicates that if inefficient farms reach the efficient frontier, a $55.76 \%$ reduction in total resource consumption could be achieved. Based on these target rates for each DMU, their environmental impacts were re-evaluated using LCA.

Table 6. Input and output amounts at current and target levels derived from the DEA method for the LCA of rain-fed barley production.

\begin{tabular}{lccc}
\hline \multicolumn{1}{c}{ Items } & Unit & \multicolumn{2}{c}{ Value } \\
\cline { 3 - 4 } & & Current & Target \\
\hline Inputs & $\mathrm{kg}$ & 161.30 & \\
1. Seed & $\mathrm{L}$ & 70.00 & 150.38 \\
2. Diesel fuel & $\mathrm{kg}$ & 11.60 & 65.00 \\
3. Machinery & $\mathrm{kg}$ & 80.50 & 10.77 \\
4. Fertilizers & $\mathrm{kg}$ & 56.70 & 75.01 \\
$\quad$ Nitrogen $(\mathrm{N})$ & $\mathrm{L}$ & 0.53 & 52.60 \\
$\quad$ Phosphate $\left(\mathrm{P}_{2} \mathrm{O}_{5}\right)$ & $\mathrm{L}$ & 1.03 & 0.49 \\
5. Chemicals & & & 0.96 \\
$\quad$ Insecticide & $\mathrm{kg}$ & 2038 & 2038 \\
$\quad$ Herbicide & $\mathrm{kg}$ & 1154 & 1154 \\
\hline $\begin{array}{l}\text { Outputs } \\
\text { 1. Barley }\end{array}$ & & & \\
2. Straw & & & \\
\hline
\end{tabular}

The environmental impact assessment derived from the LCA for the production of 1 ton of rain-fed barley at the current levels of input consumption is summarized in Figure 6 . In both the abiotic depletion and abiotic depletion (fossil fuels) indicators, the consumption of $\mathrm{N}$ fertilizer, fuel and machinery were the most important inputs. Abiotic depletion refers to the depletion of natural resources not including living organisms, such as crude oil, wind energy, etc. Thus, this indicator examines the amounts of inorganic resources used during the product life cycle.

The global warming potential (GWP100a) index is used to express the share of GHGs emitted from agricultural units. In this study, the GWP100a for rain-fed barley was $194 \mathrm{~kg}$ $\mathrm{CO}_{2}$ eq/ton of product. In a study conducted by Mondani et al. [48], this index for irrigated and rain-fed wheat cultivation was 680.36 and $381.30 \mathrm{~kg} \mathrm{CO} 2 \mathrm{eq} /$ ton, respectively. Soltani et al. [51] obtained an index of $291 \mathrm{~kg}$ of $\mathrm{CO}_{2} \mathrm{eq} /$ ton of crop for wheat cultivation in the northern region of Iran. In Ghasemi-Mobtaker et al. [36], the GWP100a for wheat cultivation was reported to be $624.30 \mathrm{~kg} \mathrm{CO}_{2}$ eq/ton of crop. In this analysis, $\mathrm{N}$ fertilizer had the greatest impact on this index, accounting for $49 \%$ of the total. Thus, improving performance requires finding alternatives to using $\mathrm{N}$ fertilizers to reduce GHGs. Houshyar [9] also concluded that a significant share of GHGs results from $\mathrm{N}$ fertilizer in wheat cultivation. Del Grosso et al. [52] reported the GWP index decreased by reducing N fertilizer application in a no-till system. The indicators of photochemical oxidation, acidification, and eutrophication indicate that $\mathrm{P}_{2} \mathrm{O}_{5}$ fertilizer, $\mathrm{N}$ fertilizer, fuel, and machinery are most important in generating pollution.

The use of DEA and LCA in combination revealed the potential for reducing the consumption of energy resources and environmental emissions for rain-fed barley cultivation in western Iran (Kermanshah Province) (Figure 7). According to the DEA results, $\mathrm{N}$ fertilizer, diesel fuel, and $\mathrm{P}_{2} \mathrm{O}_{5}$ fertilizer are the inputs with the greatest opportunities for savings. Improved management of resource consumption had notable impacts on 
abiotic depletion (fossil fuels), human toxicity, marine aquatic ecotoxicity, global warming

(GWP100a), freshwater aquatic ecotoxicity, and terrestrial ecotoxicity (Table 7).

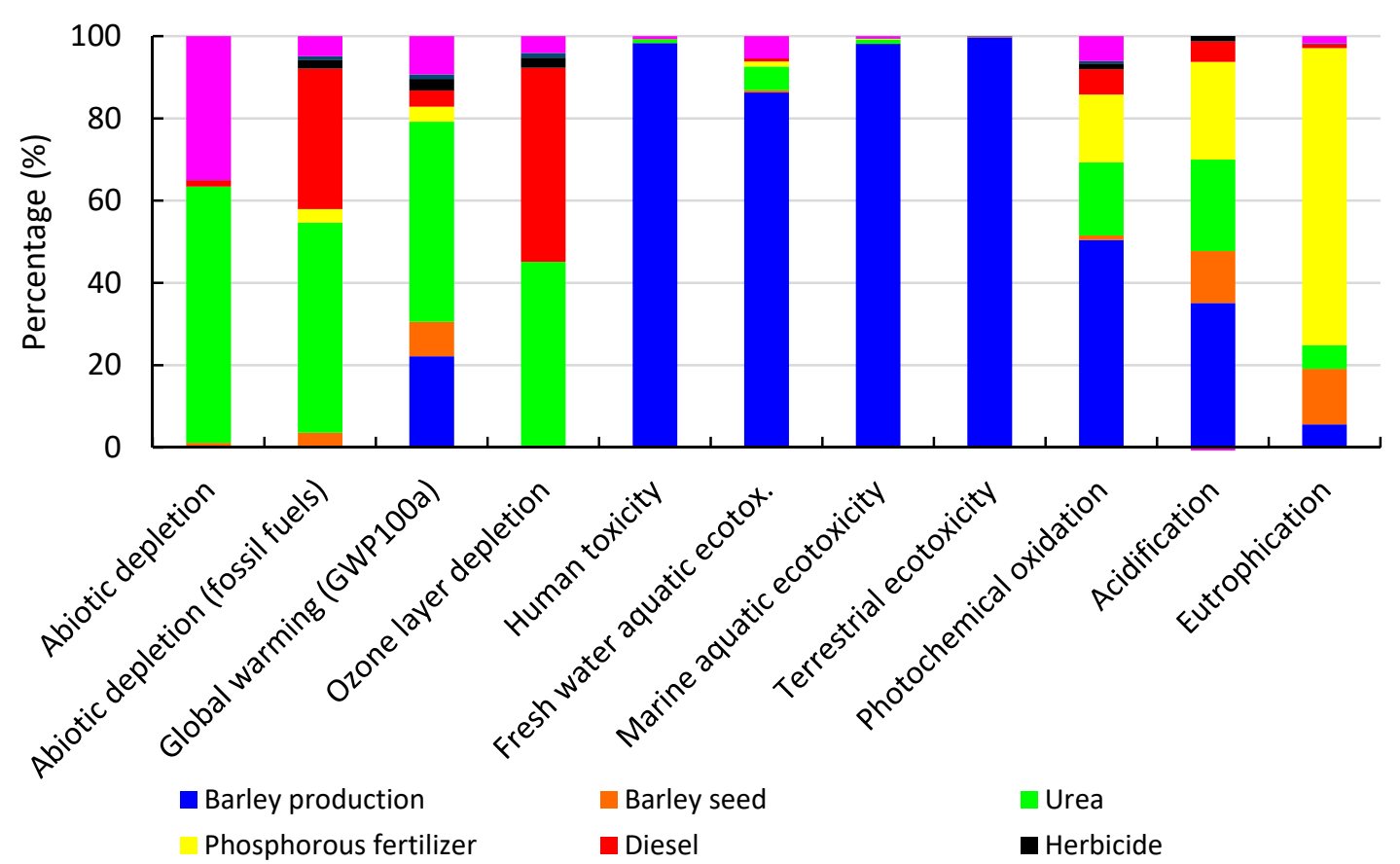

Figure 6. Environmental indicators from LCA in the current state in barley cultivation.

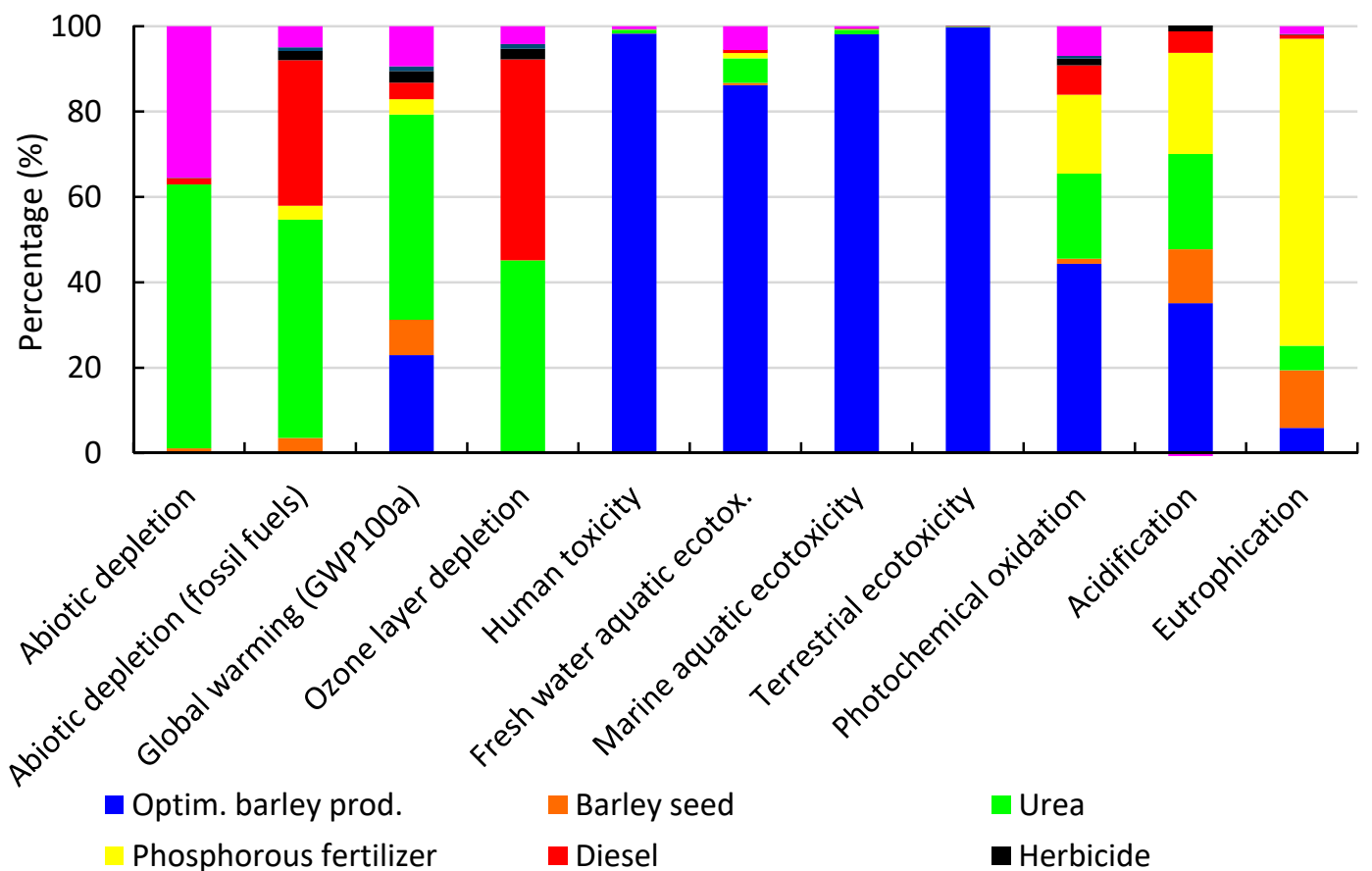

Figure 7. Environmental indicators from LCA in the optimal target state in barley cultivation.

Figures 6 and 7 show the differences in environmental emissions before and after the DEA method. Thus, Steps 2 and 4 of Figure 3 are expressed in these two figures. Figure 6 shows the environmental indicators in the current state to produce 1 ton of rainfed barley (Step 2 of Figure 3). Here, to obtain the amounts of pollutants, the collected data (Inventory data) were directly entered into SimaPro software. By contrast, Figure 7 shows the pollutants in optimized data mode (Step 4 of Figure 3). Here, the output data optimized 
with the DEA method were transferred to SimaPro software to obtain the amounts of environmental emissions.

Table 7. Comparison of the environmental impacts of barley production under current and optimized DMUs derived using DEA method.

\begin{tabular}{|c|c|c|c|c|}
\hline Impact Category & Unit & $\begin{array}{l}\text { Current Barley } \\
\text { Production }\end{array}$ & $\begin{array}{c}\text { Optimized Barley } \\
\text { Production }\end{array}$ & Differences (\%) \\
\hline Abiotic depletion & $\mathrm{kg} \mathrm{Sb} \mathrm{eq}$ & 0.0006 & 0.0005 & 16.67 \\
\hline Abiotic depletion (fossil fuels) & MJ & 3119.58 & 2906.03 & 6.84 \\
\hline Global warming (GWP100a) & $\mathrm{kgCO}_{2} \mathrm{eq}$ & 193.96 & 183.03 & 5.63 \\
\hline Ozone layer depletion (ODP) & $\mathrm{kg}$ CFC-11 eq & $2.92 \times 10^{-5}$ & $2.72 \times 10^{-5}$ & 6.86 \\
\hline Human toxicity & kg 1,4-DB eq & 5665.76 & 5173.48 & 8.69 \\
\hline Fresh water aquatic ecotox. & $\mathrm{kg} 1,4-\mathrm{DB}$ eq & 201.07 & 186.99 & 7.00 \\
\hline Marine aquatic ecotoxicity & $\mathrm{kg} 1,4-\mathrm{DB}$ eq & $4,178,056$ & 387,976 & 90.71 \\
\hline Terrestrial ecotoxicity & $\mathrm{kg} 1,4-\mathrm{DB}$ eq & 105.31 & 97.78 & 7.15 \\
\hline Photochemical oxidation & $\mathrm{kg} \mathrm{C}_{2} \mathrm{H}_{4} \mathrm{eq}$ & 0.10 & 0.08 & 17.08 \\
\hline Acidification & $\mathrm{kg} \mathrm{SO}_{2} \mathrm{eq}$ & 1.64 & 1.52 & 7.07 \\
\hline Eutrophication & $\mathrm{kg} \mathrm{PO}_{4} \mathrm{eq}$ & 1.66 & 1.54 & 6.81 \\
\hline
\end{tabular}

$\mathrm{N}$ fertilizer is the most important pollutant contributing to abiotic depletion, abiotic depletion (fossil fuels), global warming (GWP100a), ozone layer depletion (ODP), photochemical oxidation, and acidification. Based on the analysis of $\mathrm{N}$ fertilizer use in the energy section, it is possible to achieve a $6.82 \%$ optimization by reducing $\mathrm{N}$ fertilizer by $5.49 \mathrm{~kg} / \mathrm{ha}$. Reducing the consumption of N fertilizer will lead to a reduction in the GWP100a category from 193.96 to $183.03 \mathrm{~kg} \mathrm{CO}$ eq (Table 7).

According to the results shown in Table 7, managing and optimizing energy consumption can have some substantial impacts on the emissions of environmental pollutants. Among the categories, the highest decrease was observed for marine aquatic ecotoxicity, abiotic depletion, and photochemical oxidation with percentage reductions of 90.71, 16.67, and 17.08, respectively, due largely to reductions of $\mathrm{N}$ fertilizer and fossil fuel consumption.

For comparison, Mohammadi et al. [53] reported an $11 \%$ decrease in the total global warming index of soybean after the use of DEA, with the irrigation share declining by $63 \%$ and $\mathrm{N}$ fertilizer share by $34 \%$. In Khoshnevisan et al. [8] the global warming index of watermelon cultivation in the Kerman region was reported to be $9485.50 \mathrm{~kg} \mathrm{CO}_{2}$ eq per ha before the use of DEA and $8758.01 \mathrm{~kg} \mathrm{CO}_{2}$ eq per ha afterwards. Houshyar and Grundmann [54] concluded that by reducing N fertilizer use by $60 \mathrm{~kg} / \mathrm{ha}$, GHG emissions in no-tillage wheat decreased from 0.232 to $0.103 \mathrm{~kg} \mathrm{CO}_{2}$ eq per $\mathrm{kg}$ and in a conventional tillage wheat from 0.209 to $0.120 \mathrm{~kg}$ of $\mathrm{CO}_{2}$ eq per $\mathrm{kg}$.

According to the results shown in Table 5, the potential energy savings in $\mathrm{P}_{2} \mathrm{O}_{5}$ fertilizer is $51 \mathrm{MJ} / \mathrm{ha}$, which can result in less photochemical oxidation, acidification, and eutrophication. Fuel consumption is also an important input for addressing abiotic depletion (fossil fuels), global warming, and ozone layer depletion [55-59]. Thus, by managing fuel consumption of agricultural machinery in field operations and transportation, emissions can be reduced. The findings of this study are similar to those reported by Khoshnevisan et al. [8] and suggest the greatest energy savings can be achieved by reducing the consumption of chemical fertilizers $\left(\mathrm{N}\right.$ and $\left.\mathrm{P}_{2} \mathrm{O}_{5}\right)$, fuel, and machinery.

It is worth noting that the main methodological difference in LCA + DEA methods and its variants are the way in which environmental variables are treated. Figures 6 and 7 identify research gaps and provide insights into the limitations and potential in the LCA + DEA framework. The LCA + DEA approach reveals the link between operational efficiency and environmental impacts, quantifying the environmental consequences of operational inefficiencies. The application of LCA to the virtual targets quantitatively verifies whether the operational benchmarking leads to a better environmental performance.

In summary, this study can offer important guidance for decision makers regarding the relative efficiency of Iranian agriculture. This is achieved by the capacity of the 
sustainability-oriented LCA + DEA approach to deal with operational and environmental aspects. This method has proven to be particularly helpful when multiple inventory data are available for similar entities. Future research with be needed, however, to further develop uses of the LCA + DEA methodology [22,60-62].

\section{Conclusions}

In this study we analyzed the optimization of energy consumption to increase energy efficiency and reduce GHG emissions in rain-fed barley production in the western region of Iran (Kermanshah Province) using DEA and LCA methods. Based on the results of the DEA method, 23 efficient farms were identified among those studied. The results showed that energy consumption could be reduced from $13,443.20$ to $12,509.27 \mathrm{MJ} / \mathrm{ha}$. Thus, $933.91 \mathrm{MJ} /$ ha of total energy could be saved in rain-fed barley cultivation without reducing yields. According to the DEA and LCA, chemical fertilizers, fuels, and machinery showed the greatest potential for energy savings and reductions in environmental impacts. By optimizing energy consumption, the greatest effects on environmental pollutants would be seen for marine aquatic ecotoxicity, photochemical oxidation, and abiotic depletion with reductions of $90.71 \%, 16.67 \%$, and $17.08 \%$, respectively.

Inefficient farmers may not be aware of best management practices and therefore do not use inputs at optimal times or amounts. Fertilization based on plant needs and the application of alternative fertilizers, such as composts, vermicomposts, green manures, etc. can play a role in reducing the consumption of chemical fertilizers. In addition, appropriate tillage methods, crop rotations, seeds suitable for the climate of the region, and irrigation management can contribute to more efficient input use. Educational efforts such as briefings, workshops, farm visits, farmer field schools (FFS), demonstration farms, etc. can support and encourage farm-management improvements as well. Using DEA and LCA, policymakers and agricultural organizations can set standard targets for resource consumption and environmental indicators in production systems. By managing resource consumption, important reductions in energy consumption and emissions of environmental pollutants can be achieved in rain-fed barley.

Author Contributions: Conceptualization, Z.P. and A.J.; methodology, Z.P. and A.J.; software, Z.P.; validation, Z.P., A.J. and S.C.; resources, S.C.; data curation, Z.P. and A.J.; writing-original draft preparation, Z.P. and A.J. writing—review and editing, T.M.-G. and S.C.; supervision, S.C. All authors have read and agreed to the published version of the manuscript.

Funding: This research received no external funding.

Conflicts of Interest: The authors declare no conflict of interest.

\section{References}

1. Ilahi, S.; Wu, Y.; Raza, M.A.A.; Wei, W.; Imran, M.; Bayasgalankhuu, L. Optimization approach for improving energy efficiency and evaluation of greenhouse gas emission of wheat crop using data envelopment analysis. Sustainability 2019, 11, 3409. [CrossRef]

2. Mohammadi, A.; Omid, M. Economical analysis and relation between energy inputs and yield of greenhouse cucumber production in Iran. Appl. Energy 2010, 87, 191-196. [CrossRef]

3. Payandeh, Z.; Kheiralipour, K.; Karimi, M.; Khoshnevisan, B. Joint data envelopment analysis and life cycle assessment for environmental impact reduction in broiler production systems. Energy 2017, 127, 768-774. [CrossRef]

4. Yuan, S.; Peng, S. Trends in the economic return on energy use and energy use efficiency in China's crop production. Renew. Sustain. Energy Rev. 2017, 70, 836-844. [CrossRef]

5. Pishgar-Komleh, S.H.; Zylowski, T.; Rozakis, S.; Kozyra, J. Efficiency under different methods for incorporating undesirable outputs in an LCA+ DEA framework: A case study of winter wheat production in Poland. J. Environ. Manag. 2020, $260,110138$. [CrossRef] [PubMed]

6. Heidari-Maleni, A.; Gundoshmian, T.M.; Jahanbakhshi, A.; Ghobadian, B. Performance improvement and exhaust emissions reduction in diesel engine through the use of graphene quantum dot (GQD) nanoparticles and ethanol-biodiesel blends. Fuel 2020, 267, 117116. [CrossRef]

7. Hesampour, R.; Bastani, A.; Heidarbeigi, K. Environmental assessment of date (Phoenix dactylifera) production in Iran by life cycle assessment. Inf. Process. Agric. 2018, 5, 388-393. 
8. Khoshnevisan, B.; Bolandnazar, E.; Shamshirband, S.; Shariati, H.M.; Anuar, N.B.; Kiah, M.L.M. Decreasing environmental impacts of cropping systems using life cycle assessment (LCA) and multi-objective genetic algorithm. J. Clean. Prod. 2015, 86, 67-77. [CrossRef]

9. Houshyar, E. Environmental impacts of irrigated and rain-fed barley production in Iran using life cycle assessment (LCA). Span. J. Agric. Res. 2017, 15, 1-6. [CrossRef]

10. Kaveh, M.; Karami, H.; Jahanbakhshi, A. Investigation of mass transfer, thermodynamics, and greenhouse gases properties in pennyroyal drying. J. Food Process Eng. 2020, e13446. [CrossRef]

11. Ghorbani, R.; Mondani, F.; Amirmoradi, S.; Feizi, H.; Khorramdel, S.; Teimouri, M.; Aghel, H. A case study of energy use and economical analysis of irrigated and dryland wheat production systems. Appl. Energy 2011, 88, 283-288. [CrossRef]

12. Mobtaker, H.G.; Keyhani, A.; Mohammadi, A.; Rafiee, S.; Akram, A. Sensitivity analysis of energy inputs for barley production in Hamedan Province of Iran. Agric. Ecosyst. Environ. 2010, 137, 367-372. [CrossRef]

13. Patil, S.L.; Ramesha, M.N. Impact of improved production technologies on chickpea yields, economics and energy use in rainfed Vertisols. Legume Res. Int. J. 2018, 41, 79-86. [CrossRef]

14. Dimitrijević, A.; Gavrilović, M.; Ivanović, S.; Mileusnić, Z.; Miodragović, R.; Todorović, S. Energy use and economic analysis of fertilizer use in wheat and sugar beet production in Serbia. Energies 2020, 13, 2361. [CrossRef]

15. Gökdoğan, O.; Erdoğan, O.; Ertan, E.; Çobanoğlu, F. Evaluation of energy and economic analysis of chestnut (Castanea sativa Mill.) fruit production in Turkey. Erwerbs-Obstbau 2019, 61, 211-216. [CrossRef]

16. Fallahpour, F.; Aminghafouri, A.; Behbahani, A.G.; Bannayan, M. The environmental impact assessment of wheat and barley production by using life cycle assessment (LCA) methodology. Environ. Dev. Sustain. 2012, 14, 979-992. [CrossRef]

17. Schmidt Rivera, X.; Bacenetti, J.; Fusi, A.; Niero, M. The influence of fertiliser and pesticide emissions model on life cycle assessment of agricultural products: The case of Danish and Italian barley. Sci. Total Environ. 2017, 592, 745-757. [CrossRef]

18. Tricase, C.; Lamonaca, E.; Ingrao, C.; Bacenetti, J.; Giudice, A.L. A comparative Life Cycle Assessment between organic and conventional barley cultivation for sustainable agriculture pathways. J. Clean. Prod. 2018, 172, 3747-3759. [CrossRef]

19. Niero, M.; Ingvordsen, C.H.; Peltonen-Sainio, P.; Jalli, M.; Lyngkjær, M.F.; Hauschild, M.Z.; Jørgensen, R.B. Eco-efficient production of spring barley in a changed climate: A Life Cycle Assessment including primary data from future climate scenarios. Agric. Syst. 2015, 136, 46-60. [CrossRef]

20. Bartzas, G.; Zaharaki, D.; Komnitsas, K. Life cycle assessment of open field and greenhouse cultivation of lettuce and barley. Inf. Process. Agric. 2015, 2, 191-207. [CrossRef]

21. Nandy, A.; Singh, P.K. Farm efficiency estimation using a hybrid approach of machine-learning and data envelopment analysis: Evidence from rural eastern India. J. Clean. Prod. 2020, 267, 122106. [CrossRef]

22. Vásquez-Ibarra, L.; Rebolledo-Leiva, R.; Angulo-Meza, L.; González-Araya, M.C.; Irarte, A. The joint use of life cycle assessment and data envelopment analysis methodologies for eco-efficiency assessment: A critical review, taxonomy and future research. Sci. Total Environ. 2020, 738, 139538. [CrossRef] [PubMed]

23. Singh, P.; Singh, G.; Sodhi, G.P.S. Energy auditing and optimization approach for improving energy efficiency of rice cultivation in south-western Punjab, India. Energy 2019, 174, 269-279. [CrossRef]

24. Laso, J.; Vázquez-Rowe, I.; Margallo, M.; Irabien, Á.; Aldaco, R. Revisiting the LCA+ DEA method in fishing fleets. How should we be measuring efficiency. Mar. Policy 2018, 91, 34-40. [CrossRef]

25. Nabavi-Pelesaraei, A.; Abdi, R.; Rafiee, S.; Mobtaker, H.G. Optimization of energy required and greenhouse gas emissions analysis for orange producers using data envelopment analysis approach. J. Clean. Prod. 2014, 65, 311-317. [CrossRef]

26. Unakıtan, G.; Aydın, B. A comparison of energy use efficiency and economic analysis of wheat and sunflower production in Turkey: A case study in Thrace Region. Energy 2018, 149, 279-285. [CrossRef]

27. Rajabi Hamedani, S.; Shabani, Z.; Rafiee, S. Energy inputs and crop yield relationship in potato production in Hamadan province of Iran. Energy 2011, 36, 2367-2371. [CrossRef]

28. Raheli, H.; Rezaei, R.M.; Jadidi, M.R.; Mobtaker, H.G. A two-stage DEA model to evaluate sustainability and energy efficiency of tomato production. Inf. Process. Agric. 2017, 4, 342-350. [CrossRef]

29. Gündoğmuş, E. Energy use on organic farming: A comparative analysis on organic versus conventional apricot production on small holdings in Turkey. Energy Convers. Manag. 2006, 47, 3351-3359. [CrossRef]

30. Ziaei, S.M.; Mazloumzadeh, S.M.; Jabbary, M. A comparison of energy use and productivity of wheat and barley (case study). J. Saudi Soc. Agric. Sci. 2015, 14, 19-25. [CrossRef]

31. Charnes, A.; Cooper, W.W.; Rhodes, E. Measuring the efficiency of decision making units. Eur. J. Oper. Res. 1978, 2, 429-444. [CrossRef]

32. Banker, R.D.; Charnes, A.; Cooper, W.W. Some models for estimating technical and scale inefficiencies in data envelopment analysis. Manag. Sci. 1984, 30, 1078-1092. [CrossRef]

33. Scheel, H. Operations Research and Wirtschaftsinformatik. In EMS: Efficiency Measurement System Users Manual; Ver. 1.3; University of Dortmund: Dortmund, Germany, 2000.

34. Nemece, T.; Huguenin-Elie, O.; Dubois, D.; Gaillard, G.; Schaller, B.; Chervet, A. Life cycle assessment of Swiss farming systems: II. Extensive and intensive production. Agric. Syst. 2011, 104, 233-245. [CrossRef] 
35. Nemecek, T.; Kägi, T.; Blaser, S. Life Cycle Inventories of Agricultural Production Systems; Final Report Ecoinvent v2.0 No. 15; Agroscope Reckenholz-Taenikon Research Station ART, Swiss Centre for Life Cycle Inventories: Zurich, Switzerland; Dübendorf, Switzerland, 2007.

36. Ghasemi-Mobtaker, H.; Kaab, A.; Rafiee, S. Application of life cycle analysis to assess environmental sustainability of wheat cultivation in the west of Iran. Energy 2020, 193, 116768. [CrossRef]

37. Naderi, S.; Raini, M.G.N.; Taki, M. Measuring the energy and environmental indices for apple (production and storage) by life cycle assessment (case study: Semirom county, Isfahan, Iran). Environ. Sustain. Indic. 2020, 6, 100034. [CrossRef]

38. Weiler, V. Carbon Footprint (LCA) of Milk Producfion Considering Multifunctionality in Dairy Systems: A study on SmallHolder Dairy Production in Kaptumo, Kenya. MSc. Thesis, Wageningen University, Wageningen, Netherlands, 2013.

39. Jahanbakhshi, A.; Kheiralipour, K. Influence of vermicompost and sheep manure on mechanical properties of tomato fruit. Food Sci. Nutr. 2019, 7, 1172-1178. [CrossRef] [PubMed]

40. Esengun, K.; Gündüz, O.; Erdal, G. Input-output energy analysis in dry apricot production of Turkey. Energy Convers. Manag. 2007, 48, 592-598. [CrossRef]

41. Taki, M.; Soheili-Fard, F.; Rohani, A.; Chen, G.; Yildizhan, H. Life cycle assessment to compare the environmental impacts of different wheat production systems. J. Clean. Prod. 2018, 197, 195-207. [CrossRef]

42. Neira, D.P.; Montiel, M.S.; Cabeza, M.D.; Reigada, A. Energy use and carbon footprint of the tomato production in heated multi-tunnel greenhouses in Almeria within an exporting agri-food system context. Sci. Total Environ. 2018, 628, $1627-1636$. [CrossRef] [PubMed]

43. Nabavi-Pelesaraei, A.; Rafiee, S.; Mohtasebi, S.S.; Hosseinzadeh-Bandbafha, H.; Chau, K.W. Energy consumption enhancement and environmental life cycle assessment in paddy production using optimization techniques. J. Clean. Prod. 2017, 162, 571-586. [CrossRef]

44. Cerutti, A.K.; Bruun, S.; Beccaro, G.L.; Bounous, G. A review of studies applying environmental impact assessment methods on fruit production systems. J. Environ. Manag. 2011, 92, 2277-2286. [CrossRef] [PubMed]

45. Singh, G.; Singh, S.; Singh, J. Optimization of energy inputs for wheat crop in Punjab. Energy Convers. Manag. 2004, 45, 453-465. [CrossRef]

46. Abdollahpour, S.H.; Zaree, S. Evaluation of wheat energy balance under rain fed farming in Kermanshah. J. Agric. Sci. Sustain. Prod. 2009, 2, 97-106. (In Persian)

47. Fatolahi, H.; Rafiee, S.; Mousavi-Avval, S.H. Assessment of the energy, economic and environmental indices of rainfed and irrigated wheat production (case study: Lorestan province). Iran. J. Biosyst. Eng. 2017, 48, 527-537. (In Persian)

48. Mondani, F.; Aleagha, S.; Khoramivafa, M.; Ghobadi, R. Evaluation of greenhouse gases emission based on energy consumption in wheat Agroecosystems. Energy Rep. 2017, 3, 37-45. [CrossRef]

49. Jahanshahloo, G.R.; Alirezaee, M.R. Measuring the efficiency of academic units at the teacher training university. J. Econ. Manag. Q. J. Islamic Azad. Univ. 1994, 20, 1-13.

50. Chauhan, N.S.; Mohapatra, P.K.; Pandey, K.P. Improving energy productivity in paddy production through benchmarking-An application of data envelopment analysis. Energy Convers. Manag. 2006, 47, 1063-1085. [CrossRef]

51. Soltani, A.; Rajabi, M.H.; Zeinali, E.; Soltani, E. Energy inputs and greenhouse gases emissions in wheat production in Gorgan, Iran. Energy 2013, 50, 54-61. [CrossRef]

52. Del Grosso, S.J.; Ojima, D.S.; Parton, W.J.; Mosier, A.R. Simulated effects of tillage and timing of N fertilizer application on net greenhouse gas fluxes and $\mathrm{N}$ losses from agricultural soils in the Midwestern USA. In Proceedings of the Third International Symposium: Non-CO2 Greenhouse Gases: Scientific Understanding, Control Options and Policy Aspects, Maastricht, The Netherlands, 21-23 January 2002; pp. 23-28.

53. Mohammadi, A.; Rafiee, S.; Jafari, A.; Dalgaard, T.; Knudsen, M.T.; Keyhani, A.; Hermansen, J.E. Potential greenhouse gas emission reductions in soybean farming: A combined use of life cycle assessment and data envelopment analysis. J. Clean. Prod. 2013, 54, 89-100. [CrossRef]

54. Houshyar, E.; Grundmann, P. Environmental impacts of energy use in wheat tillage systems: A comparative life cycle assessment (LCA) study in Iran. Energy 2017, 122, 11-24. [CrossRef]

55. Shekofteh, M.; Gundoshmian, T.M.; Jahanbakhshi, A.; Heidari-Maleni, A. Performance and emission characteristics of a diesel engine fueled with functionalized multi-wall carbon nanotubes (MWCNTs-OH) and diesel-biodiesel-bioethanol blends. Energy Rep. 2020, 6, 1438-1447. [CrossRef]

56. Jahanbakhshi, A.; Salehi, R. Processing watermelon waste using Saccharomyces cerevisiae yeast and the fermentation method for bioethanol production. J. Food Process Eng. 2019, 42, e13283. [CrossRef]

57. Mesri-Gundoshmian, T.; Heidari-Maleni, A.; Jahanbakhshi, A. Evaluation of performance and emission characteristics of a CI engine using functional multi-walled carbon nanotubes (MWCNTs-COOH) additives in biodiesel-diesel blends. Fuel 2021, 287, 119525. [CrossRef]

58. Salehi, R.; Taghizadeh-Alisaraei, A.; Jahanbakhshi, A.; Shahidi, F. Evaluation and measurement of bioethanol extraction from melon waste (Qassari cultivar). Agric. Eng. Int. CIGR J. 2018, 20, 127-131.

59. Heidari-Maleni, A.; Mesri-Gundoshmian, T.; Jahanbakhshi, A.; Karimi, B.; Ghobadian, B. Novel environmentally friendly fuel: The effect of adding graphene quantum dot (GQD) nanoparticles with ethanol-biodiesel blends on the performance and emission characteristics of a diesel engine. NanoImpact 2021, 21, 100294. [CrossRef] 
60. Bagheri, A.; Sohrabi, N. Predicting yield of rainfed and irrigated barley (Hordeum vulgare L.) in Kermanshah by Artificial Neural Network approach (Case study Kermanshah, Iran). Agroecology 2018, 2, 516-528.

61. Mohammadi, A.; Rafiee, S.; Jafari, A.; Keyhani, A.; Dalgaard, T.; Knudsen, M.T.; Hermansen, J.E. Joint life cycle assessment and data envelopment analysis for the benchmarking of environmental impacts in rice paddy production. J. Clean. Prod. 2015, 106, 521-532. [CrossRef]

62. Martín-Gamboa, M.; Iribarren, D.; García-Gusano, D.; Dufour, J. A review of life-cycle approaches coupled with data envelopment analysis within multi-criteria decision analysis for sustainability assessment of energy systems. J. Clean. Prod. 2017, 150, 164-174. [CrossRef] 